\title{
Prognostic factors for frequent episodic asthma in children
}

\author{
Sulaiman Hamid ${ }^{1 *}$, Amalia Setyati ${ }^{2}$, Noormanto ${ }^{2}$ \\ Department of Pediatrics, Faculty of Medicine, Universitas Gadjah Mada, Dr. Sardjito \\ Hospital, Yogyakarta
}

\begin{abstract}
Asthma is a major health problem affecting millions of children worldwide. The prevalence of asthma in children tends to increase annually in the world. Therefore, identification of the prognostic factors for episodic asthma is important to perform early prevention of asthma attacks in children. The study was performed to identify the prognostic factors for frequent episodic asthma in children. This was a retrospective cohort study involving asthmatic children who attended the Emergency Unit or Outpatient Clinic of the Department of Pediatrics, Dr. Sardjito General Hospital, Yogyakarta. The inclusion criteria were asthmatic children aged over 7 years, suffering from asthma over 2 years and getting agreement from their parents as expressed by signed an informed consent. The exclusion criteria were children with other chronic obtructive pulmonary diseases beside asthma and children with cardiovascular diseases. Subjects were grouped into two groups i.e. Case Group and Control Group. The Case Group was children with frequent episodic asthma while the Control Group was children with infrequent episodic asthma. Prognostic factors for episodic asthma were then gathered by giving a questionnaire to their parents. Regression analysis was used to evaluate the relationship between prognostic factors and episodic asthma. A total of 94 subjects comprising $37(36.4 \%)$ subjects with frequent episodic asthma and 57 (63.6\%) subjects with infrequent episodic asthma were involved in the study. Furthermore, response to initial theraphy was significantly associated with frequent episodic asthma $(R R=8.64 ; 95 \% \mathrm{Cl}=0.47-2.50 ; p=0.001)$. Whereas, nutritional status, patients age when asthma diagnosed, exclusive breastfeeding, maternal education, exposure of secondhand smoke and welfare were not $(p>0.05)$. In conclusion, the initial therapy is prognostic factors for frequent episodic asthma in children.
\end{abstract}

\section{ABSTRAK}

Asma merupakan masalah kesehatan utama yang mempengaruhi jutaan anak di dunia. Prevalensi asma pada anak cenderung naik setiap tahun di dunia. Oleh karena itu identifikasi faktor prognostik terjadinya serangan asma penting untuk melakukan tindakan pencegahan dini terhadap serangan asma pada anak. Penelitian ini dilakukan untuk mengkaji faktor prognostik terjadinya asma pada anak. Penelitian ini merupakan penelitian kohort retrospektif yang melibatkan anak penderita asma yang berkunjung ke Unit Kedaruratan atau Klinik Rawat Jalan, Bagian Anak, RSUP Dr. Sardjito, Yogyakarta. Kriteria inklusi adalah anak penderita asma lebih dari 7 tahun, menderita asma lebih dari 2 tahun dan mendapatkan persetujuan dari orang tuanya dengan menandatangani surat pernyataan persetujuan. Kriteria eksklusi adalah anak pederita asma dengan gangguan paru obstruktif dan kardiovaskuler. Subjek dikelompokkan menjadi 2 kelompok yaitu Kelompok Kasus dan Kelompok Kontrol. Kelompok Kasus adalah anak yang sering mendapatkan serangan asma dan Kelompok Kontrol adalah anak yang jarang mendapatkan serangan asma. Faktor prognosis diperoleh melalui kuesioner terhadap orang tuan anak. Analisis regresi digunakan untuk mengkaji hubungan antara faktor prognosis dengan terjadinya serangan asma. Sebanyak 94 subjek terdiri dari 37 (36.4\%) anak yang sering mendapatkan serangan asma dan 57 (63.6\%) anak yang jarang mendapatkan serangan asma terlibat dalam penelitian. Selanjutnya dilaporkan, respon terhadap

\footnotetext{
* corresponding author: sulaimanhamid@ymail.com
} 
terapi awal berhubungan bermakna dengan kejadian serangan asma yang sering pada anak ( $R R=$ $8,64 ; 95 \% \mathrm{Cl}=0,47-2,50 ; \mathrm{p}=0,001)$. Sedangkan status gizi, umur penderita ketika didiagnosis asma, ASI eksklusif, pendidikan ibu, paparan asap rokok dan kesejahteraan orang tua tidak berkaitan dengan kejadian serangan asma yang sering $(p>0.05)$. Dapat disimpulkan, respon terhadap terapi awal merupakan prognostik terjadinay serangan asma yang sering pada anak.

Keywords: prognostic factor - frequent episodic asthma - children - initial therapy - diagnose

\section{INTRODUCTION}

Asthma is a complex syndrome that affects both children and adults. The main characteristic of asthma is the occurrence of airway obstruction, bronchial hiperresponsivity and airway inflammation. ${ }^{1}$ Asthma is a major public health problem affecting millions of children worldwide. The prevalence of asthma in children tends to increase annually. In United State, asthma prevalence in children increased from $3.6 \%$ in 19080 to $5.8 \%$ in 2003 . The increase of asthma prevalence is also reported in other countries in the world. ${ }^{2}$ The prevalence of asthma in children in some cities in Indonesia has been reported with different results. In Yogyakarta, the prevalence of asthma in primary school children was $4.8 \%$ and in Bandung was $5.2 \%$. Whereas studies conducted in Jakarta reported the prevalence of asthma in children was $11.5 \%$ and $6.7 \% .^{2,3}$

Asthma poses a significant public health burden. Asthma is associated with reduced health-related quality of life. Patients with clinically stable nocturnal asthma are found to have poorer cognitive performance and poorer subjective and objective sleep quality compared with healthy subjects. ${ }^{6}$ Asthma is also strongly associated with frequent mental distress such as frequent physical distress, frequent activity limitations, frequent anxiety, and frequent sleeplessness. ${ }^{7}$ In addition, patients with asthma are found to have mentally or physically unhealthy days and days with activity limitations. ${ }^{4}$
The study was performed to identify the predictor factors for frequent episodic asthma in children. Identification of the predictor factors is important to perform early prevention of asthma attacks in children.

\section{MATERIALS AND METHODS}

\section{Subjects}

This was a retrospective cohort study involving asthmatic children who attended the Emergency Unit or Outpatient Clinic of the Department of Pediatrics, Dr. Sardjito General Hospital, Yogyakarta and met inclusion and exclusion criteria. The inclusion criteria were asthmatic children aged over seven years, suffering from asthma over two years and getting agreement from their parents as expressed by signed an informed consent. The exclusion criteria were children with other chronic obtructive pulmonary diseases beside asthma and children with cardiovascular diseases. The study has been approved by the Medical and Health Research Ethics Committee, Faculty of Medicine, Universitas Gadjah Mada, Yogyakarta.

\section{Protocol of study}

Subjects who attended the Emergency Unit or Outpatient Clinic were selected. An explanation concerning the background, objectives and benefit of the study was given to the parents. The subjects who fulfilled the inclusion and exclusion criteria, an informed consent was given to their parents to be signed. 
Subjects were then grouped into two groups i.e. Case Group and Control Group based on episodic asthma according to National Guidelines for Asthma in Children. The Case Group was children with frequent episodic asthma while the Control Group was children with infrequent episodic asthma. Subjects were considered to have frequent episodic asthma if subjects experienced asthma attacks over than one time in one month with moderate exacerbations for less than one week. Whereas subjects were considered to have infrequent episodic asthma if subjects experienced asthma attacks less than one time in one month with mild exacerbations for less than one week. Primary data were then gathered from the medical record of subjects, whereas secondary data were gathered by giving a questionnaire to the parents of subjects. The questionnaire consisted of interview administrative questions concerning characteristics of subjects, frecuency of asthma attacks and risk factors for asthma episode including obesity, onset of asthma, response to early therapy, exposure of secondhand smoke, non exclusive breastfeeding, education of mother and income.

\section{Stastitical analysis}

Data were tabulated and statistically analyzed. Univariate analysis was performed for numerical data. Unpaired t test was applied to compare numerical variables, whereas Chi square was applied to compare unpaired categorical variables. Logistic regression test was used to assess correlation between independent variables and dependent variable. Multivariate regression analysis was used to analyse correlations between some the independent variables and dependent variable.

\section{RESULTS}

A total of 96 subjects who met the inclusion and exclusion criteria were involved in the study, however two subjects were excluded due to heart diseases during the study. Therefore, there were 94 subjects comprising 54 (57.4\%) male and 40 (42.6\%) female who finished their participation in the study. Furthermore, 37 (36.4\%) subjects were identified to have frequent episodic asthma and 57 (63.6\%) subjects had infrequent episodic asthma. The characteristics of subjects are presented in TABLE 1 . No significantly different in the characteristics of subjects was observed between the Case Group and the Control Group ( $>0.05)$.

TABLE 1. Characteristics of subjects

\begin{tabular}{lccc}
\hline Variables & $\begin{array}{c}\text { Frequent episodic asthma } \\
\text { group } \\
(\text { Case Group) } \\
\mathrm{n}=37\end{array}$ & $\begin{array}{c}\text { Infrequent episodic } \\
\text { asthma group (Control } \\
\text { Group) } \\
\mathrm{n}=57\end{array}$ & p value \\
\hline Sex $(\mathrm{n}$ or $\%)$ & & & \\
* Male & $23(43 \%)$ & $26(65 \%)$ & 0.456 \\
* Female & $14(35 \%)$ & $29.12 \pm 16.78$ & 0.697 \\
Patients age when diagnosed (month) & $30.38 \pm 16.53$ & $54.86 \pm 17.48$ & 0.707 \\
Duration of follow up (month) & $53.62 \pm 16.53$ & $473.000 \pm 314.5000$ & 0.0890 \\
Income per capita (IDR)* & $398.000 \pm 339.800$ & & \\
\hline
\end{tabular}

* Indonesian Rupiah 
The possibility of prognostic factors that caused frequent episodic asthma comprising initial theraphy, nutritional status, patients age when asthma diagnosed, exclusive breastfeeding, maternal education, exposure of secondhand smoke and welfare have been evaluated using simple logistic regression analysis continued by multivariate regression analysis. The result of the simple logistic regression analysis is presented in TABLE 2.

TABLE 2. Simple logistic regression analysis of prognostic factors for frequent episodic asthma

\begin{tabular}{lccc}
\hline Variables & RR & $95 \%$ CI & P value \\
\hline Nutritional staus & 0.75 & $0.18-3.21$ & 0.69 \\
Patients age when asthma diagnosed & 1.09 & $0.47-2.50$ & 0.84 \\
Response to initial therapy & 8.64 & $2.24-33.36$ & 0.001 \\
Exclusive breastfeeding & 1.41 & $0.59-3.36$ & 0.44 \\
Mother's education & 0.92 & $0.21-4.09$ & 0.91 \\
Exposure of secondhand smoke & 2.26 & $0.97-5.27$ & 0.06 \\
Welfare & 1.08 & $0.44-2.70$ & 0.86 \\
\hline
\end{tabular}

The result showed that only response to initial theraphy was significantly associated with frequent episodic asthma $(\mathrm{RR}=8.64$; 95\%CI= 2.24-33.36; $\mathrm{p}=0.001$ ). Whereas, nutritional status, patients age when asthma diagnosed, exclusive breastfeeding, maternal education, exposure of secondhand smoke and welfare were not ( $\mathrm{p}>0.05)$.

Further analysis using multivariate regression, variable that had $\mathrm{p}<0.25$ i.e. initial therapy and variables that considered play an important role as prognostic of asthma i.e. nutritional status, patients age when asthma diagnosed, exclusive breastfeeding were included in the analysis. The result showed that only initial therapy was significantly associated with frequent episodic asthma $(\mathrm{RR}=9$; 95\% $\mathrm{CI}=2-33$; $\mathrm{p}=0.002$ ) indicating that initial therapy was prognostic factor for frequent episodic asthma. Asthmatic children who poor responsed to initial therapy had a nine times greater risk of experiencing frequent episodic asthma compared to those good responsed.

\section{DISCUSSION}

This study found that the prevalence of asthma in male children was higher than in female children. Asthma prevalence studies have been conducted in some countries with different results. In China, the prevalence of asthma in males children are significantly higher than females children. ${ }^{8}$ However, in United State showed, female children have higher asthma prevalence than male children. ${ }^{9}$ In Australia, in over 14 years age group females have higher asthma than males. However, in the 0-14 year group, males have higher asthma than females. ${ }^{10}$ Country differences in asthma prevalence in children may be correlated with poverty, urban air quality, indoor allergens, lack patient education and inadequate medical care.

The prevalence of infrequent episodic asthma (57\%) was higher than that frequent episodic asthma (43\%). This result was similar with a study conducted by Asterina et al. ${ }^{11}$ that reported the prevalence of infrequent episodic asthma (68\%) was higher than that frequent episodic asthma (32\%). However, the prevalence of frequent episodic asthma in this study was higher than that 
previous study conducted by Asterina et al. ${ }^{11}$ Furthemore, the mean age of patients when asthma diagnosed in this study was $30.38 \pm 16.53$ months for patients with frequent episodic asthma and $29.12 \pm 16.78$ months for patients with infrequent episodic asthma. Asterina et al. ${ }^{11}$ reported that the mean age of patients when asthma diagnosed was 2.8 years or 33.6 months.

The possibility of prognostic factors for frequent episodic asthma comprising initial theraphy, nutritional status, patients age when asthma diagnosed, exclusive breastfeeding, maternal education, exposure of secondhand smoke and welfare have been evaluated in this study. However, only initial theraphy was proven to be the prognostic factor and the others factors evaluated was not proven.

The initial therapy as prognostic factor of frequent episodic asthma has been reported in previous studies. Bacharier et al. ${ }^{12}$ reported that persistent asthma symptoms was associated with the response to initial therapy. Another study showed that chidren under two years who suffered severe asthma attacks more than one days had high risk of persistent asthma. ${ }^{13}$

Poor response to initial therapy especially to $\beta 2$-agonist may be caused by $\beta 2$-adrenoceptor polymorphism. Drazen et al. ${ }^{14}$ reported that â2adrenoceptor polymorphism decreased response to $\beta 2$-agonist. The $\beta 2$-adrenoceptor polymorphism causes reduction in binding ability of agonist, coupling to adenylate cyclase and functional desensititation. The poor response to the initial therapy prolongs the inflammation of respiratory tract lead to induction of remodeling process. The remodeling of the respiratory tract causes failure in the treatment of asthma with its consequences.

\section{CONCLUSION}

In conclusion, initial theraphy is proven to be pronostic factor of frequent episodic asthama in children. Whereas, nutritional status, patients age when asthma diagnosed, exclusive breastfeeding, maternal education, exposure of secondhand smoke and welfare were not. Asthmatic children who have poor response to initial therapy have a nine times greater risk of experiencing frequent episodic asthma compared to those have good initial response.

\section{ACKNOWLEDGEMENTS}

Authors would like to thank all children and their parents who have participated in the study. We would like also to thank Head of Department of Pediatric, Faculty of Medicine/Dr. Sardjito General Hospital for his permission to perform the study.

\section{REFERENCES}

1. Global Initiative for Asthma. Global strategy for asthma management and prevention 2014. [cited 2014 September 5]. Available from:www.ginasthma. org

2. Eder W, Ege MJ, von Mutius E. The asthma epidemic. N Engl J Med. 2006; 355(21):222635.

3. Naning R. Prevalensi asma pada murid sekolah dasar di Kotamadya Yogyakarta. Yogyakarta: Bagian Ilmu Kesehatan Anak FK UGM, 1992.

4. Rahajoe N, Supriyatno B, Setyanto DB. Pedoman nasional asma anak. Cetakan ke 2. Jakarta: UKK Pulmonologi PP IDAI, 2004.

5. Ford ES, Mannino DM, Homa DM, Gwynn C, Redd SC, Moriarty DG, et al. Self-reported astma and health related quality of life: findings from the behavioral risk factor surveillance system. Chest. 2003; 123(1):119-27.

6. Lockey RF, DuBuske LM, Friedman B, Petrocella V, Cox F, Rickard K. Noctural asthma: effect of salmeterol on quality of life and clinical outcomes. Chest. 1999; 115(3):666-73.

7. Strine TW, Ford ES, Balluz L, Chapman DP, Mokdad AH. Risk behaviors and health-related quality of life among adults with asthma: the role of mental health status. Chest. 2004; 126(6):1849-54.

8. Bai J, Zhao J, Shen KL, Xiang L, Chen AH, Huang $\mathrm{S}$, et al. Current trends of the prevalence of 
childhood asthma in three Chinese cities: a multicenter epidemiological survey. Biomed Environ Sci 2010; 23(6):453-7.

9. Akinbami LJ, Moorman JE, Bailey C, Zahran HS, King M, Johnson CA, et al. Trends in asthma prevalence, health care use, and mortality in the United States, 2001-2010. NCHS Data Brief 2012; 94:1-8.

10. Australian Buereau of Statistic. Asthma [cited 2014, June 15]. Available from: http:// www.abs.gov.au/ausstats/abs@.nsf/Lookup/ 4338.0main+features152011-13

11. Asterina R, Siregar SP, Madiyanto B, Suprayitno B. Clinical manifesttions of childhood asthma persisting until the age of seven. Pediatric Indonesiana 2004; 44:1-6.

12. Bacharier LB, Boner A, Carlsen KH, Eigenmann PA, Frischer T, Gotz M, et al. Diagnosis and treatment of asthma in childhood: a PRACTALL consensus report. Allergy. 2008; 63(1):5-34.

13. Potter PC. Current for the management of asthma in young children. Allergy Asthma Immunol Res. 2010; 2(1):1-13.

14. Drazen JM, Silverman EK, Lee TH. Heterogeneity of therapeutic responses in asthma. Br Med Bull 2000; 56(4):1054-70. 